\title{
Changes In Intracranial Pressure in Patients with External Ventricular Drainage of CSF During Nursing Interventions
}

1 Nives Črnila

1 University Hospital Centre Sestre milosrdnice, Zagreb, Croatia

Article received: 08.02.2021.

Article accepted: 29.06.2021.

Author for correspondence:

Nives Črnila

Department of Anesthesiology, Intensive Care Medicine and Pain Management

University Hospital Centre Sestre milosrdnice

Vinogradska cesta 29, 10000 Zagreb, Croatia

E-mail: nivescopak92@gmail.com

https://doi.org/10.24141/2/5/2/1

Keywords: intracranial pressure, nursing care, analgesia, sedation, neurotrauma, coma, drainage

\section{Abstract}

Introduction. When managing intracranial pressure (ICP) disorders, that is, deviations from the normal value ( $5-15 \mathrm{mmHg}$ ), it helps to understand the variability of cerebral blood volume and cerebrospinal fluid.

Aim. To explore from a series of cases the impact of nursing interventions on the increase of intracranial pressure and the possibility of preventive action on possible oscillations of measured pressure values by modifying sedation and analgesia in order to avoid potentially negative effects on brain injury.

Methods. The study included six patients, with the average age of 59 years, hospitalized between December 2018 and May 2019, on whom measurements were performed before, immediately after and 30 minutes after the end of a particular intervention using an external drainage and monitoring system. Intracranial pressures of patients in an induced coma were compared with those who were in a natural coma.

Results. During morning nursing care and aspiration of secretions, an increase in the mean value of ICP was observed immediately after the intervention, but the t-test for dependent samples showed that it was not statistically significant, while in massaging patients with turning it to the side it was statistically significant. Combining all interventions into one, without categorization, there was also a statistically significant increase in intracranial pressure immedi- 
ately upon completion of morning nursing care. After 30 minutes, the pressure values in all interventions approach the initial value and remain within the deviation of $1 \mathrm{mmHg}$.

Conclusion. Most nursing interventions are associated with a slight increase in ICP that is not statistically significant. Greater oscillations were observed in patients in an induced coma than in those in a natural coma, which could probably have been avoided by even stricter titration of analgosedation immediately before and during nursing interventions.

\section{Introduction}

The volume of the central nervous system is constant, so it is wrong to think of pathological ICP as the result of the "extra volume" in the intracranial space (1). Namely, if a massive lesion such as a hematoma, neoplasm, or parenchymal edema occurs, the other components must be displaced, and the final volume must remain unchanged (1). Because the brain is made up of three components, the parenchyma, the cerebrospinal fluid, and the vascular part, an increase in one of these volumes causes a decrease in the other two, with a concomitant increase in intracranial pressure (1). The normal range of intracranial pressure is usually $5-15 \mathrm{mmHg}$ (2). In addition to pathological events, whose indirect indicator is the reactivity or non- reactivity of the pupils to light and motor function, the height of intracranial pressure can be influenced by some external factors. For example, inappropriate position of neurosurgical patients, airway obstruction, fever, and irregular and difficult defecation accompanied by strain and pain lead to an acceleration of metabolism, and consequently to an increase in intracranial pressure (3). While preventing the abovementioned, it is necessary to prevent complications of prolonged lying down, perform skin care and passive breathing exercises. In the case of a restless patient, it is necessary to prevent injury and calm him down (sedate him). Adhering to the rules of asepsis, it is also necessary to control the patency of the cerebrospinal fluid drainage system and the condition of the ventricular catheter. Although most nursing interventions are aimed at alleviating or eliminating predictors of increased intracranial pressure and despite proper nursing care, different interventions may directly or indirectly affect ICP. Several studies have been conducted about that connection so far. In 2013, DaiWai M. Olson, together with a team of experts, conducted a study "Effects of nursing interventions on intracranial pressure" (4). Twenty-eight patients were included in the study, and measurements were performed after the first and fifth minutes after the end of the intervention (4). The measured values varied widely, and it was concluded that the response of intracranial pressure to care-related interventions was inconsistent, which is attributed to the fact that nurses perform a wide range of interventions when providing routine care to patients whose ICP is monitored. Four years later, in the United States, a group of scientists, again led by DaiWai M. Olson, conducted research on new approaches to research about the impact of nursing care on intracranial pressure, a prospective pilot-observational study of 10 patients requiring ICP monitoring and nurses who agreed to participate (5). As the behavior of nurses was also successfully studied during the study about the pressures, it was concluded that the implementation of such a study is possible. Coordinating and analyzing mutually exclusive and exhaustive behaviors has shown that nursing behavior affects patients 'intracranial pressure (5). In 2002, a prospective non-randomized study was conducted in Milan to evaluate the impact of tracheal aspiration on intracranial dynamics in the acute phase of head injury (6). Seventeen patients with severe head injury (GCS $\leq 8$, range 4-8), sedated and mechanically ventilated, were studied during the first week after trauma by measuring blood arterial gases and jugular oxygen saturation before and after the intervention (SjO2), ICP and mean arterial pressure (MAP) and cerebral perfusion pressure (CPP) was calculated (6). In the case of patients with head injuries who cough or move, it was suggested to deepen the level of sedation before the end of the procedure in order to reduce the risk of side effects (6). A 2014 pilot study aimed to investigate the secondary consequences for patients associated with well-defined nursing interventions (7). The definition of secondary deterioration was intracranial pressure more than $20 \mathrm{mmHg}$, cerebral perfusion pressure less than $60 \mathrm{mmHg}$ and systolic blood pressure less than $100 \mathrm{mmHg}$ for 5 minutes or more, within 10 minutes of the start of nursing intervention (7). The minute of deterioration should not have been consecutive. The 
study included 18 patients. Relocation and concurrent interventions were nursing interventions that caused most of the secondary exacerbations (7). In 2001, in the Central Intensive Care Unit (ICU), Sisters of Mercy University Hospital (KBCSM), the department where the current study was conducted, a study was conducted to determine the association of neurological status expressed as the Glasgow Coma Scale with intracranial cerebral perfusion and mean arterial pressure. (8). It was concluded that monitored intracranial and cerebral perfusion pressures were well associated with GCS (8). There was no statistically significant correlation between GCS and mean arterial pressure, which the authors interpreted by iatrogenic procedures maintaining mean arterial pressure (8). For this reason, the subjects in this study were included, among other things, according to the GCS criteria. These studies served as the basis for conducting a study of the impact of nursing interventions on changes in intracranial pressure in this study. This has been extended with several additional interventions and a well-defined measurement time, including some criteria from each of the studies already conducted.

\section{Aim}

The aim is to investigate from a series of cases the extent to which nursing interventions affect the increase of intracranial pressure and whether modification of sedation and analgesia and the most gentle performance of a particular intervention can have a positive effect on the absolute value of measured pressures and thus avoid potentially negative effects on brain tissue or on the general condition of patients.

\section{Hypothesis}

$\mathrm{H} 1$ : Performing morning nursing care, which includes bathing and oral hygiene, tracheal aspiration, massage and turning of the patients, percutaneous tracheotomy and cannula replacement, significantly acutely increases intracranial pressure, but it returns to baseline after 30 minutes.

$\mathrm{H} 2$ : By adjusting sedation and analgesic therapy and with as gentle manipulations with the patient as possible, clinically significant variations in intracranial pressure can be avoided.

\section{Methods}

The sample was formed so that the study included appropriate, available subjects who were hospitalized during the study (from December 2018 to May 2019) in the neurosurgical part of the Central Intensive Care Unit, University Hospital Centre Sestre milosrdnice. Thus, four male and two adult female patients in a coma with external ventricular cerebrospinal fluid drainage (EVD) were included. The first of these, a 43-year-old male subject, was diagnosed with intracerebral hemorrhage and underwent 51 sets of measurements over fifty days in a ratio of 24 sets using analgesic sedation and 27 without medication. The next male subject, aged 21 years, was a patient diagnosed with a brain tumor and due to a short coma was a participant in 3 series of measurements in the presence of analgesia. The remaining two male patients were hospitalized for a diagnosis of intracerebral hemorrhage. The first, aged 75 years, was the subject in 25 conducted series of measurements, 12 of which in the presence of analgesia. The last, aged 62 , was a subject in 25 series of measurements, all under the influence of drug therapy. Of the two remaining subjects, the patient who was 82 years old and diagnosed with intracerebral hematoma, participated in 9 series of measurements, all without analgesia and in a natural state of coma, while the other, 68 years old, participated in 15 series of measurements, of which only one was performed without medical support. During statistical processing, patients in a state of analgesia in one group were compared with conditions without analgesia in another (GCS less than 5). Patients without analgesia are those who ended up in a coma due to pathological processes in certain parts of the brain. When measuring the value of intracranial pressure, the Duet external drainage and monitoring system, from the American company Medtronic, was used. It is a system that drains the cerebrospinal fluid by gravity. Although it can also be used for lumbar drainage, only patients with external ventricular drainage were included in the study. Monitoring is performed on each patient via the Infinity C700 and the Dräger Infinity Delta XL monitor, which is connected to the Infinity HemoMed Pod with a HemoMed cable. Through an invasive hemodynamic monitoring system that connects to the Duet switch of the external 
drainage and monitoring system, the entire system is connected to the Infinity HemoMed Floor and to the monitor itself. The invasive hemodynamic monitoring system in this case comprises $100 \mathrm{ml}$ of $0.9 \%$ sodium chloride infusion solution, a single, disposable Merit Medical invasive monitoring set and a corresponding cable that connects said set to the Infinity HemoMed Floor. Upon arrival of the patient from the operating room, the external drainage system is attached to the stand next to the patient. The connections on the system and its passability are checked. The system for measuring intracranial pressure, after it was washed, is connected to the first switch to the patient's head. Then, but also after each change of the patient's position, a laser is taken and connected to the intended part of the external drainage system at the number " 0 ". The laser also contains a spirit level that shows the plane of the number " 0 " flush with the external auditory canal (ear canal). Values are measured in millimeters of mercury. System resetting is performed three times a day or after system disconnection, by resetting the values on the monitor, by lowering the external drainage system to an overflow point of $0 \mathrm{mmHg}$. The patient lies on his back, with the headrest raised by 30 degrees. In relation to the patient, the external cerebrospinal fluid drainage system is located in the previously described plane, is at the height of the external auditory canal, which means at the height of the third cerebral ventricle. Subjects were connected to a respirator when measured via an endotracheal tube or cannula. Conducting this prospective research all data were obtained by measurement.

\section{Ethics}

The procedures carried out for the purpose of conducting research on the impact of nursing interventions on ICP changes were in line with the Helsinki Declaration and the unique requirements for Biomedical manuscripts, and the implementation was approved by the ethics committee of the Sisters of Mercy University Hospital. Also, informed consent was requested from the caregivers of the subjects involved as well as from the only subject whose state of consciousness had risen to GCS 15 during the study.

\section{Statistics}

After the distribution of the collected data into classes, descriptive statistics were conducted. The data are being shown using a histogram. Because the measurements were performed in series related to the intervention (before the start of the intervention, immediately after the end and 30 minutes after the end), t-test for dependent samples for each intervention compared values obtained before the intervention with those immediately after the intervention and the procedure was repeated to compare baseline values with those 30 minutes after the end of the intervention. The obtained results are displayed in the boxplot.

The statistical software Minitab, used for data analysis and processing, is a 2019 version.

\section{Results}

During the research, a total of 128 series of measurements were performed: 17 during bathing, 82 aspiration of secretions, and 29 when turning patients sideways with massage. As an intervention, port transport of patients for diagnostic tests was treated in the same way, but comparing the arithmetic mean of the measured pressures with respect to the state of consciousness was not possible due to the small sample $(\mathrm{N}=4)$. Also, the sample in the interventions "Percutaneous tracheotomy" and "Sampling for microbiological tests" was too small and for the same reason was not included in further statistical processing. In $31.85 \%$ of measurements, patients were analgosedated with midazolam, sufentanil, and in a few cases isoflurane. In $21.41 \%$ of measurements, continuous analgesia with sufentanil was used, and in $1.48 \%$ only sedation with midazolam was used. In $39.26 \%$ of measurements, no drug was used during the implementation of a particular intervention. Because lower, along with the cerebral cortex activating parts of the brain that continuously excite the cortex with their impulses are needed to maintain normal consciousness, coma can result from damage to the cortex or damage of the lower parts (pons and midbrain) (9). The estimated state of consciousness of the subjects ranges from GCS 3 - 5, and the condition of all included patients occurred posttraumatic or as a consequence of surgery of the tumor process on the brain. The overflow point in the patients included in 
this study, which determines at which height of the ICP the cerebrospinal fluid will begin to drain, was at 15 and $20 \mathrm{mmHg}$, respectively, and the drainage was also open at the measurement. The disadvantage of the system is the possibility of clogging with a blood clot or a piece of tissue. This happened, and consequently, the measurement values were extremely high, which is why they are only mentioned but excluded from statistical processing. In this patient, the external ventricular drainage (EVD) system was subsequently changed, while in the others the system was the same throughout the study. The results obtained during morning nursing care are shown in Table 1.

Table 1. Descriptive statistics for the intervention: morning nursing care for all respondents in whom the mentioned intervention was performed

\begin{tabular}{|l|c|c|c|c|c|}
\hline Variable & df & Mean & SD & Min & Max \\
\hline Before & 16 & 12.71 & 5.05 & 5 & 21 \\
\hline $\begin{array}{l}\text { Immediately } \\
\text { after }\end{array}$ & 16 & 15 & 7.07 & 5 & 30 \\
\hline $\begin{array}{l}30 \text { minutes } \\
\text { after }\end{array}$ & 16 & 12 & 5.17 & 3 & 23 \\
\hline
\end{tabular}

Comparing the values measured before the start of the intervention with those measured immediately after the end of the intervention, the values obtained are $t=-1.62, p=0.124$, while comparing the values before and 30 minutes after the end intervention we get $\mathrm{t}=0.64, p=0.530$. If only the values of analgosedated patients are compared with the mentioned subjects, the data obtained before the beginning of the intervention and immediately after the end, we get $t=-1.63, p=0.64, d f=5$, while in subjects without analgesic sedation we get $t=-0.67$, $p=0.519, \mathrm{df}=10$. Values measured before the start of morning nursing care and those 30 minutes after the end of nursing care of analgosedated patients show $\mathrm{t}=0.61, p=0.566$, and in patients without analgesic care $\mathrm{t}=0.28, p=0.785$ (Table 2 ).
Table 2. Descriptive statistics for the intervention: morning nursing care with a division between performing the intervention with or without analgesic sedation

\begin{tabular}{|c|c|c|c|c|c|}
\hline & $\overline{\text { Variable }}$ & Mean & SD & Min & $\operatorname{Max}$ \\
\hline \multirow{3}{*}{ 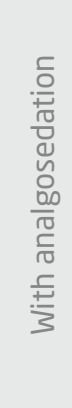 } & Before & 12 & 4.90 & 7 & 21 \\
\hline & $\begin{array}{l}\text { Immediately } \\
\text { after }\end{array}$ & 16.67 & 7.76 & 10 & 30 \\
\hline & $\begin{array}{l}30 \text { minutes } \\
\text { after }\end{array}$ & 10.67 & 4.93 & 3 & 16 \\
\hline \multirow{3}{*}{ 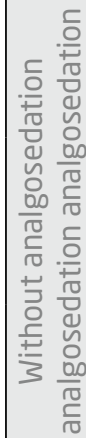 } & Before & 13.09 & 5.32 & 5 & 21 \\
\hline & $\begin{array}{l}\text { Immediately } \\
\text { after }\end{array}$ & 14.09 & 6.88 & 5 & 30 \\
\hline & $\begin{array}{l}30 \text { minutes } \\
\text { after }\end{array}$ & 12.73 & 5.39 & 7 & 23 \\
\hline
\end{tabular}

Most ICPs were measured during the "Secretion aspiration" intervention (Table 3).

Table 3. Descriptive statistics for the intervention: aspiration of secretions in all subjects in whom this intervention was performed

\begin{tabular}{|l|c|c|c|c|c|}
\hline Variable & $\mathrm{df}$ & Mean & StDev & Min & Max \\
\hline Before & 81 & 11.506 & 5.876 & 2 & 29 \\
\hline $\begin{array}{l}\text { Immediately } \\
\text { after }\end{array}$ & 81 & 11.790 & 6.561 & 1 & 33 \\
\hline $\begin{array}{l}30 \text { minutes } \\
\text { after }\end{array}$ & 81 & 11.272 & 5.831 & 2 & 30 \\
\hline
\end{tabular}

Comparing the values obtained before and immediately after the completion of the aspiration of secretions, we obtained $\mathrm{t}=-0.71, p=0.477$. Taking as a 
sample only measurements with analgosedation $t=-$ 1.56, $p=0.133, \mathrm{df}=25$, and without analgosedation $t=-0.00, p=1,000, d f=55$. Comparing the initial value of all subjects involved in this intervention with that of 30 minutes after completion interventions, $t=$ $0.74, p=0.459$ was obtained, in analgosedation $\mathrm{t}=-$ $0.42, p=0.678$, and in patients without analgosedation $\mathrm{t}=1.06, p=0.292$ (Table 4).

Table 4. Descriptive statistics for intervention: aspiration of secretions with division between performance of intervention with or without analgesic sedation

\begin{tabular}{|c|c|c|c|c|c|}
\hline & Variable & Mean & SD & Min & Max \\
\hline \multirow{3}{*}{ 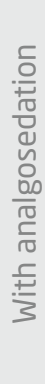 } & Before & 12.12 & 7.98 & 2 & 29 \\
\hline & $\begin{array}{l}\text { Immediately } \\
\text { after }\end{array}$ & 13.04 & 8.95 & 1 & 33 \\
\hline & $\begin{array}{l}30 \text { minutes } \\
\text { after }\end{array}$ & 12.32 & 8.26 & 2 & 30 \\
\hline \multirow{3}{*}{ 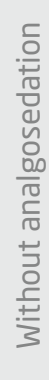 } & Before & 11.23 & 4.714 & 8 & 26 \\
\hline & $\begin{array}{l}\text { Immediately } \\
\text { after }\end{array}$ & 11.23 & 5.159 & 8 & 29 \\
\hline & $\begin{array}{l}30 \text { minutes } \\
\text { after }\end{array}$ & 10.80 & 4.354 & 8 & 25 \\
\hline
\end{tabular}

No statistically significant difference was obtained in these measurements. ICP values obtained during the massage and lateral rotation of patients are shown in Table 5 with a division into analgosedated and nonanalgosedated patients in Table 6.

Including all patients included in this intervention and comparing the values obtained before and immediately after the end of the massage and turning patients in the lateral position, $\mathrm{t}=-2.17, p=0.039$. A statistically significant difference was observed in this, which can be explained by the small number
Table 5. Descriptive statistics for the intervention: massage and turning the patient to the lateral position in all subjects in whom the said intervention was performed

\begin{tabular}{|l|c|c|c|c|c|}
\hline Variable & $\mathrm{df}$ & Mean & SD & Min & Max \\
\hline Before & 28 & 11.65 & 5.11 & 2 & 21 \\
\hline $\begin{array}{l}\text { Immediately } \\
\text { after }\end{array}$ & 28 & 13.10 & 6.66 & 1 & 30 \\
\hline $\begin{array}{l}30 \text { minutes } \\
\text { after }\end{array}$ & 28 & 12.07 & 6.31 & 2 & 26 \\
\hline
\end{tabular}

Table 6. Descriptive statistics for the intervention: massage and turning the patient to the lateral position with a division into performing the intervention with or without analgesia

\begin{tabular}{|c|c|c|c|c|c|}
\hline & Variable & Mean & SD & Min & Max \\
\hline \multirow{3}{*}{ 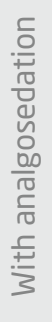 } & Before & 12.38 & 7.65 & 2 & 21 \\
\hline & $\begin{array}{l}\text { Immediately } \\
\text { after }\end{array}$ & 14.00 & 10 & 1 & 30 \\
\hline & $\begin{array}{l}30 \text { minutes } \\
\text { after }\end{array}$ & 13.13 & 8.82 & 2 & 26 \\
\hline \multirow{3}{*}{ 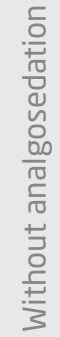 } & Before & 11.38 & 3.981 & 5 & 21 \\
\hline & $\begin{array}{l}\text { Immediately } \\
\text { after }\end{array}$ & 12.76 & 5.17 & 4 & 24 \\
\hline & $\begin{array}{l}30 \text { minutes } \\
\text { after }\end{array}$ & 11.67 & 5.28 & 6 & 25 \\
\hline
\end{tabular}

of measurements $(N=29)$, and also by the fact that even after the division of patients according to the type, we get small p values compared to other interventions. Isolating only analgesic patients, $t=-1.19$, $p=0.272, \mathrm{df}=7$ was obtained, and in those without analgesia $\mathrm{t}=1.76, p=0.094, \mathrm{df}=20$. Also, comparing the results before and 30 minutes after the interven- 
tion, $\mathrm{t}$ is $-0.72, p=0.480$. By division, in analgosedated patients $\mathrm{t}=-0.92, p=0.390$ and $\mathrm{t}=-0.38, p=0.705$ without analgosedation, respectively. In case we ignore the potentially different effect of certain interventions on ICP variations and group all measurements into a common group called "Intervention", we get the data shown in Table 7, divided into analgosedated state and a natural coma - without analgesation (Table 8).

Table 7. Descriptive statistics of all interventions in all respondents

\begin{tabular}{|l|c|c|c|c|c|}
\hline Variable & $\mathrm{df}$ & Mean & SD & Min & Max \\
\hline Before & 127 & 11.684 & 5.636 & 2 & 29 \\
\hline $\begin{array}{l}\text { Immediately } \\
\text { after }\end{array}$ & 127 & 12.571 & 6.687 & 1 & 33 \\
\hline $\begin{array}{l}30 \text { minutes } \\
\text { after }\end{array}$ & 127 & 11.571 & 5.826 & 2 & 30 \\
\hline
\end{tabular}

Table 8. Descriptive statistics for values measured for all interventions with a division between performance of the intervention with or without analgesic sedation

\begin{tabular}{|c|c|c|c|c|c|}
\hline & Variable & Mean & SD & Min & Max \\
\hline \multirow{3}{*}{ 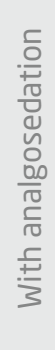 } & Before & 12.37 & 7.38 & 2 & 29 \\
\hline & $\begin{array}{l}\text { Immediately } \\
\text { after }\end{array}$ & 14.02 & 8.82 & 1 & 33 \\
\hline & $\begin{array}{l}30 \text { minutes } \\
\text { after }\end{array}$ & 12.51 & 7.76 & 2 & 30 \\
\hline \multirow{3}{*}{ 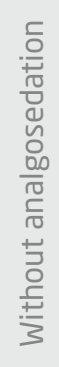 } & Before & 11.38 & 4.674 & 3 & 26 \\
\hline & $\begin{array}{l}\text { Immediately } \\
\text { after }\end{array}$ & 11.92 & 5.409 & 4 & 30 \\
\hline & $\begin{array}{l}30 \text { minutes } \\
\text { after }\end{array}$ & 11.15 & 4.714 & 2 & 25 \\
\hline
\end{tabular}

The t-test for dependent samples, before and immediately after the end of the intervention, taking as a sample all subjects included in the study, obtained $\mathrm{t}=2.51, p=0.013$, in analgosedated state $\mathrm{t}=-$ 2.68, $p=0.011, \mathrm{df}=39$ and $\mathrm{t}=-1.27, p=0.207, \mathrm{df}=87$ without analgosedation. Comparing the total results before and 30 minutes after the end of the measurement, we obtained $\mathrm{t}=0.41, p=0.685$, for analgosedated $\mathrm{t}=-0.31, p=0.756$, and for those without analgosedation $\mathrm{t}=0.66, p=0.508$. From the abovestated, two statistically significant differences can be observed $(p=0.013, p=0.011)$, both immediately after the end of the intervention, which is caused by an increase in intracranial pressure compared to the initial value measured at rest. Both increases are associated with interventions.

\section{Discussion}

Before and immediately after the intervention, taking as a sample all subjects included in the study, it was found that in most cases there is no statistically significant difference between the arithmetic means of the measured pressures before and immediately after the intervention. A small difference between the arithmetic means comparing the intracranial pressures during all interventions before the start and immediately after the end of the nursing intervention still exists in terms of the increase in ICP caused by the intervention. The largest differences in arithmetic means were recorded in the intervention "Morning nursing care", ( $\mu$ _difference: mean of (Before - Immediately after) $=-2.29 \mathrm{mmHg}$ ) in analgosedated patients ( $\mu$ _difference: mean of (AS-before - AS- immediately after) $=-4.67 \mathrm{mmHg}$ ). This can be explained by the fact that morning nursing care consists of a set of interventions, so this intervention is the most comprehensive. After 30 minutes, the pressure values in all interventions approach the initial value and remain within the deviation of $1 \mathrm{mmHg}$ from the stated value. Looking at the aforementioned research conducted around the world, it can be concluded that the same problem was examined but using different methods and under the influence of different interventions. The study conducted in North Carolina, like this current one, had a 
precisely defined measurement time (after 1 and 5 minutes from the intervention), but due to the wide range of interventions, some at the same time, it was concluded that the response of intracranial pressure to care interventions was inconsistent (4). Although different in the method of work and the inclusion of nurses as subjects in the study, a study conducted in Dallas examined the impact of nursing care on intracranial pressure and showed that behavioral care affected intracranial pressure in patients by aligning and analyzing mutually exclusive and comprehensive behaviors (5). In a study conducted in Milan, although only secretion aspiration intervention was included, patients differed by sedation groups (6). In the lastmentioned study, measurements were performed during nursing care according to a standardized procedure and almost all subjects had some harmful, secondary reaction (7). The first hypothesis, that performing morning nursing care (bathing and oral hygiene), tracheal aspiration, massage and turning patients, and the procedure of percutaneous tracheotomy and cannula replacement, significantly acutely increase intracranial pressure, but its value returns to baseline after 30 minutes, has not been proven because the observed pressure differences are not statistically significant for almost all interventions, although there is a possibility that with a larger sample and a larger number of measurements it would be possible to prove it. We can't reject the alternative hypothesis that clinically significant variations in intracranial pressure can be avoided by adjusting sedation and analgesic therapy and as gentle manipulations with the patient as possible, although it is difficult to prove it objectively based on our results. Namely, it was observed that patients in an induced coma had larger oscillations in intracranial pressure values than those in a natural coma, but these were not clinically significant. During the research itself, a small sample of respondents was encountered, which was partially bridged by a larger number of measurements in each of them during their stay in the ICU. In addition, there are a number of factors that can influence measurement errors, which have been observed and described by other authors conducting similar research. During various interventions, secretion in the endotracheal cannula appeared as a confusing factor. Since "Secretion aspiration" was not the primary study of intervention in this case, the patient would be disturbed during manipulation and a more abundant secretion would begin. Due to tracheal irritation with an aspiration catheter, the patient would in most cases start coughing in an attempt to expel the accumulated contents, vital functions would increase, and thus the intracranial pressure would increase as well. Another confusing factor was discovered when extremely high values of intracranial pressure occurred. Namely, several measurements were performed immediately before the catheter became impassable and it was necessary to replace it. The values of one measurement measured during aspiration and one during bathing were mentioned for this reason but were not statistically processed together with other results.

The study was conducted over a six-month period and included all patients who met the inclusion criteria. However, due to a certain degree of state of consciousness, i.e., GCS less than 5, the number of measurements divided by interventions is small and thus the results may be skewed ("sampling bias"). But the research conducted may be an introduction to further, longer-term research on a larger sample of patients. In different patients, measurements were performed during different interventions. Due to the short-term analgesia, but also the different length of stay in the ICU of the KBCSM, it was not possible to perform measurements during certain interventions in certain patients. The different length of follow-up made it impossible to compare ICP values between patients with one other ("measurement and detection bias"). Speaking of intracranial pressure, whose monitoring has become a common part of the treatment protocol for severe brain injuries, we are also talking about a very important indicator of mean perfusion pressure (CPP), the most reliable indicator of threatening ischemia and secondary brain injury (10). There are also different theories of ICP height reference values from different authors. Some authors take 15, some $25 \mathrm{mmHg}$ as the upper limit, but most of them agree on the limit of $20 \mathrm{mmHg}$, so the height of the ICP above it is taken as an indication for the application of therapy and therapeutic procedures in order to reduce it (10). Patients with lower GCS are more prone to intracranial hypertension, and clinical experience suggests that even a small increase in ICP lowering CPP, greatly increases the risk of brain entrapment, which worsens the prognosis and/or prolongs patients' recovery (10). Pain and psychomotor anxiety affect the acceleration of metabolism, and thus blood flow in the brain, and ultimately contribute to an increase in intracranial pressure. Properly dosed sedation contributes to the reduction of in- 
tracranial pressure, but it should be properly titrated with analgesia, paying attention to airway patency, elimination of secretions and the position of the patient (2). Opiates, benzodiazepines, and propofol are the most commonly used sedative drugs in neurological and neurosurgical intensive care units (11). Benzodiazepines, a group to which midazolam, the drug used in this study, belong, are cheaper than propofol and achieve a satisfactory sedative effect in addition to amnesia (11).

\section{Conclusion}

Based on the obtained results in which it was recognized that immediately after performing routine procedures ICP rises above the reference values, but it is not clinically significant, this can be interpreted as confirmation of relatively satisfactory titration of analgesia and sedation in the central intensive care unit. However, since a statistically significant difference was observed in analgosedated patients, there is still some space for even better titration of analgosedation directly before and during nursing interventions.

\section{Acknowledgements}

We would like to thank the nurses of the Central Intensive Care Unit, University Hospital Centre Sestre Milosrdnice, for their help in conducting this research. Without their cooperation and daily collection of the necessary data, the implementation of this research would not be possible. Also, thank you to the interim head of the Institute Primarius Marinko Vučić, MD, $\mathrm{PhD}$, and the head of the Intensive Care Unit Primarius Mladen Širanović, MD, PhD on the trust shown when approving the implementation of the research. Special thanks to my mentor, Ass. prof. Ivana Šklebar, $\mathrm{MD}, \mathrm{PhD}$, for her patience, relevant expertise, and kindness in writing this paper. Also, thank you to No- vak Martina, BA, for useful advice and help. Special thanks to my family and boyfriend for their support and understanding and for encouraging and encouraging them to achieve their goals.

\section{References}

1. Andrews TB, editor. Neurosurgical intensive care. 1st ed. USA: McGraw-Hill; 1993.

2. Bečulić $H$, Skomorac R, Jusić A, Mekić-Abazović A, Alić $F$, Dervišević $S$, et al. Osnovi neurohirurškog menadžmenta povišenog intrakranijalnog pritiska i edema mozga. Bilten Ljekarske komore. 2015;55(9):24-34. Bosnian.

3. Prlić N, Rogina V, Muk B. Zdravstvena njega bolesnika s ozljedama glave. U: Zdravstvena njega 4. 3rd ed. Zagreb: Školska knjiga; 2005. Croatian.

4. Olson DM, McNett MM, Lewis LS, Riemen KE, Bautista C. Effects of nursing interventions on intracranial pressure. Am J Crit Care. 2013;22(5):431-8.

5. Olson DM, Parcon C, Santos A, Santos G, Delabar R, Stutzman SE. A Novel Approach to Explore How Nursing Care Affects Intracranial Pressure. Am J Crit Care. 2017;26(2):136-9.

6. Gemma M, Tommasino C, Cerri M, Giannotti A, Piazzi $B$, Borghi T. Intracranial effects of endotracheal suctioning in the acute phase of head injury. J Neurosurg Anesthesiol. 2002;14(1):50-4.

7. Nyholm L, Steffansson E, Fröjd C, Enblad P. Secondary insults related to nursing interventions in neurointensive care: a descriptive pilot study. J Neurosci Nurs. 2014;46(5):285-91.

8. Novkoski M, Gvozdenović $A$, Kelečić M, Gopčević $A$, Mazul-Sunko B, Širanović M et al. Correlation between Glasgow Coma Scale Score and Intracranial Pressure in Patients with Severe Head Injury. Acta clin Croat. 2001;40(3):191-5.

9. Jelaković A, Andreis I. Poremećaji svijesti. U: Patologija i patofiziologija. Zagreb: Školska knjiga; 2006. Croatian.

10. Jukić M, Gašparović V, Husedžinović I, Majerić Kogler V, Perić M, Žunić J. Intenzivna medicina. Zagreb: Medicinska naklada; 2008. Croatian.

11. Kaal EC, Vecht CJ. The management of brain edema in brain tumors. Curr Opin Oncol. 2004;16(6):593-600. 


\section{Sažetak}

Uvod. Kod upravljanja poremećajima intrakranijskog tlaka, odnosno njegovim odstupanjima od normalne vrijednosti (5 do $15 \mathrm{mmHg}$ ), uvelike pomaže razumijevanje varijabilnosti volumena moždane krvi i cerebrospinalne tekućine.

Cilj. Istražiti utjecaj sestrinskih intervencija na povišenje intrakranijskog tlaka te mogućnost preventivnog djelovanja na moguće oscilacije izmjerenih vrijednosti tlakova modifikacijom sedacije i analgezije u svrhu izbjegavanja potencijalno negativnih učinaka na sanaciju ozljede mozga.

Metode. Istraživanjem je obuhvaćeno šestero pacijenata, prosječne dobi 59 godina, hospitaliziranih između prosinca 2018. i svibnja 2019., na kojima su s pomoću vanjskog sustava za drenažu i praćenje provođena mjerenja prije, neposredno nakon završetka i 30 minuta po završetku određene intervencije. Međusobno su uspoređivani intrakranijski tlakovi pacijenata za vrijeme inducirane kome $s$ onima u prirodnoj komi.

Rezultati. Prilikom obavljanja jutarnje zdravstvene njege i aspiracije sekreta primijećen je porast srednje vrijednosti ICP-a neposredno nakon intervencija, ali je t-testom za zavisne uzorke utvrđeno da nije statistički značajan, dok kod masaže pacijenata uz okretanje na bok jest. Objedinjujući sve intervencije u jednu, bez podjele po kategorijama, također je došlo do statistički značajnog porasta intrakranijskog tlaka neposredno po završetku. Nakon 30 minuta, vrijednosti tlakova kod svih intervencija približavaju se početnoj vrijednosti i ostaju unutar odstupanja od $1 \mathrm{mmHg}$.

Zaključak. Većina sestrinskih intervencija povezana je s blagim porastom ICP-a koji nije statistički značajan. Veće oscilacije uočene su u pacijenata u induciranoj komi nego kod onih u prirodnoj, što bi se vjerojatno moglo izbjeći još striktnijom titracijom analgosedacije neposredno prije i tijekom sestrinskih intervencija.
Ključne riječi: intrakranijski tlak, sestrinska skrb, analgezija, sedacija, neurotrauma, koma, drenaža 